\title{
GLOBALIZATION, ITS ESSENCE, CAUSES AND CONSEQUENCES
}

\author{
Dinara Abdunayimova ${ }^{1}$ \\ ${ }^{1}$ Student at Tashkent State University of Law, Tashkent, Uzbekistan \\ Email:_dinaraabdunayimova@gmail.com
}

\begin{abstract}
This article reviews the phenomenon of globalization, its essence, content and causes are analyzed in various aspects. The special attention is paid to the cultural aspect, opinions of sociologists on the distribution of heterogeneity of world culture and globalization of culture its causes and consequences are analyzed. The theme of global languages and the problem of preserving cultural identity and heritage of different nations and peoples are also revealed.
\end{abstract}

Keywords: Globalization, diversity, culture, lingua franca, unification, Americanization, westernization, McDonaldization.

\section{INTRODUCTION}

At the last two decades, Globalization and Diversity became one of the most actual topics. As a common practice, researchers highlight the following main aspects of considering globalization: economic, technological, environmental, demographic, political, informational, and cultural. This caused by several factors such as deeper international division of labour, scientific and technological progress in transport and communications, reducing the economic distance between countries and other practical and theoretical reasons. Along with the causes, Globalization has some negative and positive consequences also. This is an objective process, which is systemic, that is, it covers all spheres of life in society. As a result of globalization, the world becomes more connected and dependent on all its subjects. There is an increase both in the number of problems common to groups of states and in the number and types of integrated entities. Without touching upon the political side of the issue, we will try to find out what impact the globalization process has on the dynamics of the socio-cultural life of peoples.

Peter Denis Sutherland an Irish businessman, barrister and politician was proclaimed as a "father of globalization", and later, in 1983 an American economist and a professor at Harvard Business school Theodore Levitt published a book "The Globalization of Markets". Prof. Levitt stated that changes in technology and social behaviours allow multinational companies such as Coca-Cola and McDonald's to sell their products around the world - "Gone are accustomed differences in national or regional preferences."[2]. Theodore Levitt is considered as a person, popularized the term "Globalization"

First, let us revise some terms and conditions:

Globalization is a worldwide economic process, political and cultural integration and unification

Integration - consolidation and unification of political, economic, state and social structures within a region, a country, a world;

Unification - the process of being united or made into a whole.

Diversity - is differences in racial and ethnic, socioeconomic, geographic, and academic/professional backgrounds. People with different opinions, backgrounds (degrees and social experience), religious beliefs, political beliefs, sexual orientations, heritage, and life experience.

\section{MAIN BODY}

Globalization is a process of uniting the world into a single system of global properties. Different components of the globalization process of the world economy have been discussed quite seriously since the 60-70s of the last century, but the current level of relevance of the issue reached only in the 90s.

Globalization of the world economy is expressed in the process of changing the world space, transforming it into a single zone, opening for the free movement of goods, services, information and capital. It is also easy in this space to spread ideas and move media, contributing to the development of relevant institutional formations and setting up systems of interaction between them. 
The consequence of the globalization of world-systems is thus the emergence of a single space at the international level: cultural, information, legal and economic. In other words, the phenomenon of globalisation is not limited to the economic sphere but has a significant impact on all key spheres of society's life - ideology, culture and politics. Undoubtedly, it is this phenomenon that has been given a central role in the world economy of the new century, which consists in catalyzing the formation of a renewed world system of relations in politics and economics adapted to globalization.

\section{There some actual reasons for globalization:}

High-efficiency telecommunication systems existing today allow users to receive information in real-time, wherever they are, which makes it possible to make decisions quickly and easily, to manage international investments of capital, to cooperate in marketing and production. With the current level of globalisation and information integration, the speed of transfer of management experience and technology from abroad is increasing significantly. Conditions for the globalisation of world processes which previously remained local due to internal features appear. Thus, higher education can now be obtained at a distance from the world's leading educational institutions.

The World Wide Web is creating new effective forms of communication and is the main foundation of globalization. The world information field, i.e. the international system for the production, distribution, storage and use of information, is being constructed.

Trade liberalization and other forms of economic liberalization that have restricted protectionist policies and made world trade more liberal. As a result, a significant part of the trade barriers was removed, and customs tariffs were reduced. Besides, other liberalization measures have increased the movement of capital, labour and other factors of production between countries.

\section{Positive consequences of globalization:}

- International competition, the generation of globalization, is a powerful stimulant of production. Strong competition leads to an increase in the quality of produced goods and services. This is quite natural due to the desire of companies to rank better in international trade. As a result, they are simply forced to make products that are more attractive to relatively competitive firms.

Globalization of the world economy has led to economies of scale, resulting in lower prices and less change in the business environment.

The formation of trade unions leads to an increase in the pace of globalisation.

- $\quad$ Labour productivity is growing due to the introduction of new technological solutions.

- $\quad$ Developing countries have the opportunity to catch up with the leading economies; due to globalization of the world economy, they have some headway and time to strengthen their economic position in the world market [7].

\section{Negative consequences of globalization:}

- $\quad$ The distribution of the positive effects of globalization of the world economy is uneven. For example, in terms of industries, some of them are left to gain: personnel with the right skills and additional financing come from abroad, which causes local people to lose competitiveness and reduces the need for them. Industries from the latter list require additional funds and time for adjustment and adaptation. Often it is not possible to adapt. In this case, employees lose their jobs and entrepreneurs lose business and money. Changes in this plan affect the national economies of individual countries, lead to higher unemployment and forced changes in economic structures.

A continuation of the previous trend is the phenomenon of the deindustrialisation of the economy. The balance in this case shifts from manufacturing to services. Local people often need to retrain to adapt to the changes caused by the globalization of the world system, to change their skills to find new jobs in other industries.

The pay gap for workers with and without qualifications is widening. While the wages of educated workers are growing, unskilled workers have to settle for very modest wages, if there is any work left for them. However, if viewed differently, it acts as an incentive for the development, training and professional advancement of employees.

The impact of globalization is changing the ecosystem and increasing the potential for conflicts over the ownership and use of natural resources. Unsustainable use of forests, water and other resources can be a major cause of such conflicts. The damage that such activities cause to the planet and its inhabitants may be irreparable.

Some of the growing problems in the impact of globalization on culture. In parallel with economic and trade globalization, culture is also being imported and exported. The problem is that stronger, larger countries such as the US can trap the cultures of other, smaller countries, causing their traditions and values to disappear. This process is also sometimes referred to as Americanization or McDonaldization.

\section{Example of Globalization No. 1 (Contemporary Globalization).}

An example of more real and already modern globalization is the European Union, where many aspects of a common unifying concept are present. The economies of the EU member states are closely linked, which allows them to develop in a normal competitive environment and, in some cases, receive 
some form of support. The political situation in the EU is still ambiguous, but the pan-European institutions show themselves quite effectively, as they try to take into account the interests of all the member states. Cultural and territorial contradictions are very rare, as due to the conditionality of borders, cultures adapt gently in a common environment.

It goes without saying that in the EU there are a lot of issues to work on, but the trend towards coexistence shows good results in many areas of life.

\section{Features of cultural development.}

In conditions of world globalization, there is a tendency to homogeneity in mass art, popular culture and mass media, distribution of English as lingua franca.

In the most general sense, culture is a set of customs and traditions, values and norms, meanings and ideas, sign and symbolic systems, knowledge, skills and abilities, cognitive and behavioural stereotypes (both in objectivized and subjectivized forms) that are characteristic of certain social communities and groups.

Globalization has sharply aggravated the problem of preserving cultural identity, which is now considered by scientists of different specialities: political scientists, sociologists, philosophers, psychologists, and is actively discussed in society. Moreover, the fear of Americanization (westernization), which is most often associated with cultural globalization, and fears of losing one's own identity stand out in public discourse.

Identity implies that a person and a community of people are aware of their real place in the natural and social world, drawing a line between "their" and "others", defining the circle of persons with whom an individual is connected and consciously identifies itself, and the circle of persons to which he or she opposes. The preconditions for identity formation are the assimilation of values and norms of a certain ("own") socio-cultural community, which, in turn, is possible only based on their opposition to another ("foreign") normative-value system, as well as the presence of a clear idea of the surrounding reality itself, allowing a person to find his or her place in it. However, in the context of globalization, this becomes extremely difficult.

The "ideologists" of globalization, primarily the US, link it to the process of "blurring" national and cultural differences between countries, to the homogenization and universalization of the world. As the only possible model of economic development, the world is offered a model developed in the countries of the West, the principles of democracy of the Western-type are declared the best way of political organization, mass culture and imposed to the whole world as a model to follow.

The process of globalization is accompanied by strong trends towards homogenization, the blurring of distinctions between nations and social groups, and the destruction of traditions, rites and values inherent in national cultures. Deprived of traditional mechanisms for the production and dissemination of cultural values, national cultures lose the ability to reproduce themselves, which leads to cultural homogenization, often referred to as "McDonaldization" or "coca-colization" of culture, since McDonald's and Coca-cola are one of its characteristic symbols [8].

Economic globalization and migration will only increase in the future, but preserving the cultural identity of nations and nationalities, and cultural diversity in general, is crucial in this context. In recent years, the world community has become acutely aware of this issue, as demonstrated, for example, by the adoption of the "UNESCO Universal Declaration on Cultural Diversity" by the 31st session of the UNESCO General Conference, which states that "cultural diversity is as necessary for humankind as biodiversity is for nature. In this sense, it is the common heritage of humanity and should be recognized and affirmed for the benefit of present and future generations" [12].

In response to the globalization challenges of cultural unification and the movement towards a cultural and polar world, the process of differentiation of local civilizations as cultural and historical areas is increasing. According to several researchers, today 12 local civilizations can be distinguished (although there are other possible classifications):

- four Western civilizations (Western European, Eastern European, North American, Latin American),

- five eastern (Japanese, Chinese, Indian, Buddhist, Muslim) and

- three mixed (Eurasian, African, oceanic)" [6, p. 19].

All civilizations differ significantly in geographic location, climatic conditions, population size, economic indicators, political structure, and military force. But these differences are not the basis for their hierarchical ranking.

It should be noted that cultural globalization has two sides: on the one hand, there is the expansion of Western (mainly American) culture to other regions of the world, and on the other hand, "there is a phenomenon of 'reverse globalization', in which people move from underdeveloped regions of the world the Middle East, Africa and South-East Asia - to globalized cities such as London and Paris, Frankfurt and Rome, Madrid and Amsterdam" [3]. At the same time, immigrants bring their culture to new habitats: language, religion, customs, national cuisine, and others, thus creating a unique transcultural environment 
for which R. Robertson proposed the term "glocalization", which combines the meaning of the two words: "globalization" and "localization" [10].

\section{English as lingua franca}

The acquisition of English as a global language represents an unprecedented phenomenon in the history of languages and cultures and has profound implications not only for language learning theory and practice but also for the preservation of the linguistic and cultural heritage of the planet. The increasing level and scope of language research are set out in the concept of the global system of languages by Abram de Swaan, Professor of Sociology at the University of Amsterdam, in his monograph "Words of the World. The Global Linguistic System", published in 2001.

According to Abram de Swaan, more than 6,000 languages represent a coherent language system linked together by multilingual speakers. Depending on the capacity of languages to act as vehicles of interlinguistic communication, de Swaan divides the world system of languages into four hierarchical groups: 1) peripheral languages; 2) central languages; 3) super-central languages; 4) hyper-central languages are generally not used for inter-linguistic communication [1].

The group of peripheral languages includes most of the so-called small languages in danger of extinction, as speakers of these languages have to use other languages in the process of communication outside their language groups [1, p.4].

Central languages ( 100 of them) are used as a means of communication between speakers of peripheral languages within geographical areas.

The super-central group includes 12 languages: Arabic, Chinese, English, German, French, Japanese, Malay, Portuguese, Russian, Swahili, Hindi and Spanish. International super-central languages have gained status as a result of their wide geographical spread and because they are unusually large languages, with more than 100 million speakers (except Swahili).

Hyper-central languages are global languages that are used to communicate between super-central speakers. The group of hyper-central languages includes only English, whose number of speakers, including both the first (L1) and second (L2) languages, is currently approaching 2 billion [11].

A. de Swaan states that "... language learning mostly takes place in the upper direction ... people usually prefer to learn a language which is at a higher level of hierarchy" $[8, \mathrm{p}$. 5]. In the hierarchy of the global language system, the only hyper-central language is English. Although it is inferior to Chinese as the first language, it is far superior to any other language in its centrality as a universal means of overcoming inter-linguistic and intercultural barriers. English learning, therefore, offers the greatest advantages, so it is no surprise that English is always the preferred language in education systems around the world when choosing a second language.

The global language system is not new, but in a period of globalization, with unprecedented growth in international connections, the need for a worldwide means of overcoming inter-linguistic and intercultural barriers has led to a change in the relationship between languages, and English has acquired global language status.

\section{CONCLUSION}

To conclude, Globalization did not appear "out of blue", centuries of progress and evolution have led to it, with the help of modern technologies such as the Internet - this process has accelerated and began to unite the inhabitants of the planet. This phenomenon has both positive and negative consequences which should be applied for the benefit of humanity. But most importantly, humanity must do everything in its power to preserve ethnic and cultural diversity and try to prevent our planet from becoming "faded" in its cultural heritage.

\section{REFERENCES}

1. 1992. De Swaan A. Words of the World. The Global Language System. Cambridge: Polity, 2001

2. Barnaby J. Feder. The New York Times - Theodore Levitt, 81, Who Coined the Term 'Globalization', Is Dead (2006)

3. Benkhabib S. Prityazaniya kul'tury. Ravenstvo i raznoobrazie v global'nuyu epokhu. M., 2005. P. XXXIII.

4. Berger L. Kulturnaya dinamika globalizacii // Mnogolikaya globalizaciya. Kulturnoe raznoobrazie v sovremennom mire / Pod red. P. Bergera, S. Hantingtona. M., 2004.

5. Delyagin M.G. Mirovoj krizis: Obshaya teoriya globalizacii: Kurs lekcij. M., 2003.

6. Dialog civilizaciya. Povestka dnya / sost. i obsh. red. V. I. Tolstyh. M., 2005.

7. ICC World Business Organization. World globalization 
8. Lysak I.V. Problema sohraneniya kulturnoj identichnosti v usloviyah globalizacii // Gumanitarnye i socialno-ekonomicheskie nauki. 2010. № 4. S. 91-93

9. Makarevich E.F., Karpuhin O.I. Globalnye kommunikacii i kulturno-politicheskaya ekspansiya // Socialno-gumanitarnye znaniya. 2007. № 3. S. 61-76.

10. Robertson R. Globalization: Social Theory and Global Culture. London,

11. S.K. Gural, V.M. Smokotin. Yazyk vsemirnogo obsheniya i yazykovaya i kulturnaya globalizaciya

12. UNESCO Universal Declaration on Cultural Diversity, adopted by the 31 st session of the General Conference of UNESCO, Paris, 2 November 2001 